University of Nebraska - Lincoln

DigitalCommons@University of Nebraska - Lincoln

USDA National Wildlife Research Center - Staff Publications
U.S. Department of Agriculture: Animal and Plant Health Inspection Service

$6-2010$

\title{
Why don't rats and mice vomit? A behavioral and anatomical investigation
}

C. C. Horn

University of Pittsburgh Cancer Institute Div. Gastro

National Wildlife Res. Ctr

National Wildlife Res. Ctr

G.R. Gathright

National Wildlife Res. Ctr

B. Yates

University Pittsburgh

P.L. Andrews

St. George's University London

Follow this and additional works at: https://digitalcommons.unl.edu/icwdm_usdanwrc

Part of the Environmental Sciences Commons

Horn, C. C.; National Wildlife Res. Ctr; Gathright, G.R.; Yates, B.; and Andrews, P.L., "Why don't rats and mice vomit? A behavioral and anatomical investigation" (2010). USDA National Wildlife Research Center Staff Publications. 1041.

https://digitalcommons.unl.edu/icwdm_usdanwrc/1041

This Article is brought to you for free and open access by the U.S. Department of Agriculture: Animal and Plant Health Inspection Service at DigitalCommons@University of Nebraska - Lincoln. It has been accepted for inclusion in USDA National Wildlife Research Center - Staff Publications by an authorized administrator of DigitalCommons@University of Nebraska - Lincoln. 
This article is a U.S. government work, and is not subject to copyright in the United States.

Why don't rats and mice vomit? A behavioral and anatomical investigation

C.C. HORN ${ }^{1, *}$, B.A. KIMBALL ${ }^{2,3}$, G.R. GATHRIGHT ${ }^{2}$, B. YATES ${ }^{4}$, P.L. ANDREWS ${ }^{5}{ }^{1}$ University of Pittsburgh Cancer Institute Div. Gastro., Hepatol., \& Nutrition, Pittsburgh, PA, USA ${ }^{2}$ National Wildlife Res. Ctr., USDA-APHIS-WS, Fort Collins, CO, USA ${ }^{3}$ Monell Chemical Senses Ctr., Philadelphia, PA, USA ${ }^{4}$ University Pittsburgh, Department Otolaryngology, Pittsburgh, PA, USA ${ }^{5}$ St. George's University London, Div. Basic Med. Sci., London, United Kingdom

Laboratory rats and mice are known to lack a vomiting response and the dimensions of the abdominal esophagus might be an important constraint (Andrews, 1995, Physiol. Zool.). However, a broad evaluation of Rodentia is lacking. Here we determined the behavioral responses and esophageal and diaphragm anatomy from 4 of the 5 Suborders. We used prototypical emetic agents, apomorphine (s.c.), veratrine (s.c.), and copper sulfate (i.g.), which are thought to produce emesis by action on the area postrema, nodose ganglia, and vagal afferent fibers, respectively. None of the rodents, including nutria (Myocastor coypus), beavers (Castor canadensis), mountain beavers (Aplodontia rufa), voles (Microtus townsendii), guinea pigs, and laboratory rats and mice vomited. In rodents, $\sim 72 \%$ of the diaphragm area was muscle compared to $100 \%$ in emetic control species (musk shrews and cats). The abdominal esophagus was also relatively long and narrow in rodents (esophageal circumference/length $\leq 0.7$, rodents, vs. $\geq 0.8$ in emetic species). These data indicate, (1) a lack of vomiting is a common feature in rodents, and (2) rodents might have anatomical constraints on their ability to vomit.

doi:10.1016/j.appet.2010.04.088 